The study was supported by grants from the Swedish Medical Research Council, the Lundberg Foundation for Scientific Research, and the Swedish Board for Technical Development. We also acknowledge the skilful technical work of Susanne Schmeisser.

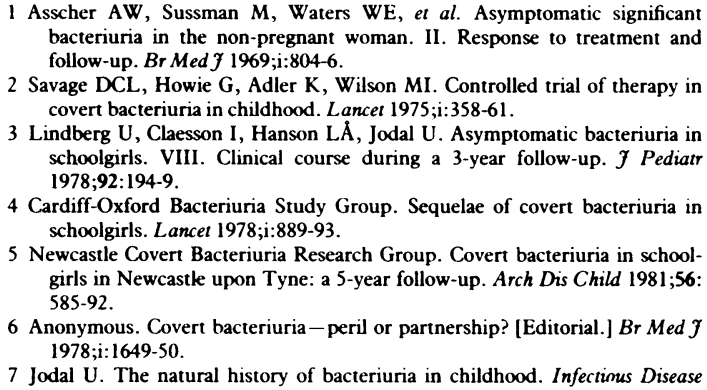
bacteriuria in the non-pregnant

2 Savage DCL, Howie G, Adler K, Wilson MI. Controlled trial of therapy in covert bacteriuria in childhood. Lancet 1975; i:358-61.

3 Lindberg U, Claesson I, Hanson LÅ, Jodal U. Asymptomatic bacteriuria in schoolgirls. VIII. Clinical course during a 3-year follow-up. $\mathcal{J}$ Pediatr 1978;92:194-9.

4 Cardiff-Oxford Bacteriuria Study Group. Sequelae of covert bacteriuria in schoolgirls. Lancet 1978; : $889-93$

5 Newcastle Covert Bacteriuria Research Group. Covert bacteriuria in schoolgirls in Newcastle upon Tyne: a 5-year follow-up. Arch Dis Child 1981;56: 585-92.

6 Anonymous. Covert bacteriuria-peril or partnership? [Editorial.] $\mathrm{Br} \mathrm{Med} \mathcal{J}$ 1978;i:1649-50.

7 Jodal U. The natural history of bacteriuria in childhood. Infectious Disease Clinics of North America 1987;1:713-29.
8 Jodal $\mathrm{U}$, Lindberg $\mathrm{U}$, Lincoln $\mathrm{K}$. Level diagnosis of symptomatic urinary tract infections in childhood. Acta Paediatr Scand 1975;64:201-8.

Hodson CJ, Wilson S. Natural history of chronic pyelonephritic scarring. BrMed f 1965;ii:191-4.

10 Ericsson HM, Sherris JC. Antibiotic sensitivity testing. Acta Pathologica et Microbiologica Scandinavica (B) 1971;217(suppl):1-90.

11 Lidin-Janson G, Falsen E, Jodal U, Kaijser B, Lincoln K. Characteristics of antibiotic-resistant Escherichia coli in the rectum of healthy schoolchildren. f Med Microbiol 1977; 10:299-308.

12 Caugant DA, Levin BR, Orskov I, Orskov F, Svanborg-Edén C, Selander RK. Genetic diversity in relation to serotype of Escherichia coli. Infect Immun 1985; 49:407-13

13 Stamey T, Govan D, Palmer J. The localization and treatment of urinary tract infections: the role of bactericidal urine levels as opposed to serum levels. Medicine 1965;44:1-26.

14 Heimdahl A, Nord CE. Effect of phenoxymethylpenicillin and clindamycin on the oral, throat and faecal microflora of man. Scand f Infect Dis 1979;11 233-42.

15 Zinner SK, Sabath LD, Casey J, et al. Erythromycin and alkalinisation of the urine in the treatment of urinary tract infections due to Gram-negative bacilli. Lancet $1971 ; \mathrm{i}: 1267$

(Accepted 23 fanuary 1989)

\title{
Self referral to an accident and emergency department for another opinion
}

\author{
Christopher S Jones, Alastair McGowan
}

\begin{abstract}
Objective-To determine whether patients re-
\end{abstract} ferring themselves to an accident and emergency department for another opinion after consulting their general practitioner present with serious illness, show any risk factors for being admitted, or are more likely to be patients of particular practitioners.

Design-Six month prospective survey.

Setting-District general hospital's accident and emergency department, receiving 42000 new patients a year.

Patients - 180 Patients identified as attending for another opinion having already consulted a general practitioner.

Interventions-Classified as admission, referral to specialist clinic, follow up in accident and emergency department, or referral back to general practitioner.

End point-Admission, with an analysis of admitted patients.

Measurements and main results-General outcome, diagnostic category, age, time of attendance, time since seen by general practitioner, and name of general practitioner were recorded. Forty seven patients were admitted, 99 were discharged back to the general practitioner (62 without a letter), and two died. Patients were most likely to be admitted if they attended within 24 hours after seeing a general practitioner, were aged under 5 , or presented with respiratory or gastrointestinal complaints. Some general practitioners were overrepresented.

Conclusions - Important disorders present in this way, and therefore these patients should be seen by a doctor. Information about these attendances could be useful to general practitioners in reviewing their performance.

\section{Introduction}

In this accident and emergency department we noticed an increasing tendency for patients to refer themselves for another opinion after consulting their general practitioner. We thought that this resulted from a breakdown in communication between some patients and their doctors, which resulted in patients not being referred. One previous study has measured this tendency,' but little else is known about these attendances. These patients may be regarded as inappropriately attending the accident and emergency department, and some departments send them back to their general practitioner. ${ }^{2}$ This may be unsafe if important illness presents in this way.

Our aims were, firstly to estimate the amount of serious illness presented in this way as indicated by the general outcome in all patients and medical outcomes in patients admitted; secondly, to analyse some basic demographic features to see if particular groups were at increased risk of being admitted; and, thirdly, to determine whether these attendances were sporadic or whether particular practitioners were overrepresented. This information might be helpful to general practitioners when examining their techniques of consultation or referral.

\section{Subjects and methods}

We carried out a prospective survey from 1 November 1987 to 30 April 1988. Patients referring themselves for another opinion after consulting their general practitioner were identified by staff at reception and their record cards marked. They were defined as those with problems for which they had previously consulted their general practitioner and who had not been referred to the accident and emergency department. Patients who claimed that they were unable to contact or obtain a visit from their general practitioner and those who had been told to attend if their conditions deteriorated were excluded. These exclusions were made to confine the study to patients who deliberately had not reconsulted the doctor they had already seen.

The data analysed were diagnostic category, age, sex, time of attendance, time elapsed since general practitioner had been consulted, whether a letter had been sent to the general practitioner, the name of the general practitioner, and what happened to the patient after attending. The hospital records of those patients admitted were further inspected for length of stay, final diagnosis, and outcome. When appropriate the significance of the data was assessed by the $\chi^{2}$ test with Yates's correction. 
TABLE I-General outcome of 180 patients who referred themselves to accident and emergency department

\begin{tabular}{lc}
\hline & $\begin{array}{c}\text { No of } \\
\text { patients }\end{array}$ \\
\hline Discharged to own doctor & 99 \\
Admitted & 47 \\
Followed up as outpatient & 19 \\
Followed up in department & 13 \\
Unknown & 2 \\
\hline
\end{tabular}

*Includes one patient who died in the department.

\section{Results}

During the study there were 20449 new attendances. Of these, $180(<1 \%)$ were self referrals for another opinion. The sex ratio was about equal (female:male $1: 1 \cdot 2)$. Table I gives details of the 47 patients $(26 \%)$ admitted, of whom two, aged 3 and 4, died (one of these patients died in the department). Table II gives the reason for attendance grouped into 16 diagnostic categories. Twenty three of the 32 patients with traumatic problems were discharged without follow up. Fifty one patients presented with respiratory or gastrointestinal complaints, of whom $27(53 \%)$ were admitted; this was a significantly greater rate of admission than that for all other categories combined $(20 / 129(16 \%), p<0.001)$.

TABLE II-Classification of diagnosis for patients who referred themselves to accident and emergency department

\begin{tabular}{lcc}
\hline Diagnostic group & $\begin{array}{c}\text { Patients } \\
\text { admitted }\end{array}$ & $\begin{array}{c}\text { Patients not } \\
\text { admitted }\end{array}$ \\
\hline Trauma & 1 & 31 \\
Gastrointestinal & 14 & 17 \\
Soft tissue infection & 4 & 18 \\
Non-traumatic orthopaedics & 13 & 20 \\
Respiratory & 4 & 7 \\
Otorhinolaryngology & 2 & 8 \\
Dermatology & 1 & 9 \\
Ophthalmology & 1 & 7 \\
No illness detected & 1 & 5 \\
Genitourinary & 4 & 1 \\
Neurology & 1 & 2 \\
Unclassified & 1 & 1 \\
Infectious diseases & & \\
Dentistry & 1 & \\
Dsychiatry & 1 & \\
\hline Tied in department & 47 & 133
\end{tabular}

There were two peaks in the age distribution: 41 patients were aged under 5 (15 under 12 months) and 79 patients were aged 15-34 (table III). Of the 41 aged under 5, $24(59 \%)$ were admitted; this was a significantly greater proportion than the proportion of the remainder admitted $(23 / 139(17 \%), p<0.001)$. This significance was unchanged even when the six children under 5 who attended between $9 \mathrm{pm}$ and 9 am were excluded (see below). The patients aged 15-34 had a relatively low rate of admission (eight patients (10\%)).

Most attendances (149) occurred in three main time periods, covering 10 hours: 9 am- 2 pm, 3 pm- 5 pm, and $6 \mathrm{pm}-9 \mathrm{pm}$ (table IV). Only 21 patients attended between $9 \mathrm{pm}$ and 9 am the next morning; 10 of these were admitted, a significantly greater proportion than the proportion admitted during the day $(37 / 159(23 \%)$, $\mathrm{p}<0.02)$. Six of the 10 admitted, however, were under 5 years old, and the policy of the paediatric department was to admit all children attending after $9 \mathrm{pm}$. When these children were excluded there was no significant difference in the rate of admission at night.

The records of 137 patients had a note of the time since the primary consultation. This ranged from a few hours to, in one extreme case, a year. Patients who attended on the same day showed a higher rate of admission (16/30 (53\%)) than those who attended more than 24 hours afterwards $(23 / 107(22 \%), p<0 \cdot 001)$. Of the 99 patients discharged immediately back to their own doctors, only 37 were given a letter. Even in the case of the 20 patients given a prescription only eight were given letters.

The 180 patients were divided among 82 general practitioners from 48 practices. Table $\mathrm{V}$ shows the number of patients who attended from each of the 33 local practices. Over half of the general practitioners (44) had only one patient recorded and $68(83 \%)$ had from one to three. Some, however, had considerably more. Some large group practices were understandably well represented. Some practices, however, were disproportionately overrepresented-for example, one practice with seven partners had seven patients attending, whereas one practice with two partners had 10 and another practice with two partners had 21. Analysis of the patients admitted showed a similar pattern, with the same practitioners and practices being overrepresented.

Inpatient records were traced for 43 of the 47 patients admitted. The duration of admission ranged from less than a day to 42 days (mean 6.8 days). Two patients stayed in hospital less than one day; one died in the department, and one was allowed home later on the same day (a possible glaucoma was diagnosed as iridocyclitis by the ophthalmologist). The mode was 3 days (10 patients), and 13 patients stayed in hospital one week or more. Only six were discharged the next day. Of the 43 patients, two died (1\% of attendances, $5 \%$ of admissions). One aged 4 died of bacterial meningitis; the other was a 3 year old who presented in extremis, sustained cardiorespiratory arrest, and could not be resuscitated; necropsy showed evidence of a chest infection. Nineteen patients were discharged back to their general practitioner with no follow up in hospital, and 22 were followed up as outpatients. Table VI lists all diagnoses noted in the discharge summary for patients admitted.

For children aged under 5 the rate of admission was $59 \%(24 / 41)$ with a mean duration of stay of $5 \cdot 4$ days. Half of the attendances occurred between $6 \mathrm{pm}$ and 9 $\mathrm{pm}(20 / 41)$, during which time the admission rate was $55 \%$ (11 patients). Between $9 \mathrm{pm}$ and 10 am the next morning one sixth of the patients aged under 5 attended (seven patients), and all were admitted. One of these seven children died, and the hospital records of a child with bilateral fractured clavicles were not traced; the mean duration of stay of the five remaining children was 8.4 days.

\section{ILLUSTRATIVE CASE REPORTS}

Case 1-A 69 year old man with a history of Parkinson's disease was seen by his general practitioner for the new complaint of fresh rectal bleeding. Haemorrhoids were diagnosed, and he was prescribed

TABLE $\mathrm{v}-$ Number of patients from each of 33 local practices who referred themselves to accident and emergency departments according to number of partners in practice

\begin{tabular}{|c|c|c|c|}
\hline \multirow{2}{*}{$\begin{array}{l}\text { Practice } \\
\text { No }\end{array}$} & \multirow{2}{*}{$\begin{array}{l}\text { No of partners } \\
\text { in practice }\end{array}$} & \multicolumn{2}{|c|}{ No of patients } \\
\hline & & Admitted & Not admitted \\
\hline 1 & 2 & 11 & 10 \\
\hline 2 & 6 & 1 & 10 \\
\hline 3 & 5 & 2 & 8 \\
\hline 4 & 2 & 1 & 9 \\
\hline 5 & 2 & & 9 \\
\hline 6 & 4 & 4 & 4 \\
\hline 7 & 3 & 4 & 4 \\
\hline 8 & 2 & 3 & 5 \\
\hline 9 & 7 & 3 & 4 \\
\hline 10 & 5 & 3 & 3 \\
\hline 11 & 1 & 2 & 4 \\
\hline 12 & 3 & & 6 \\
\hline 13 & 2 & 3 & 2 \\
\hline 14 & 1 & 1 & 4 \\
\hline 15 & 3 & & 5 \\
\hline 16 & 1 & & 5 \\
\hline 17 & 5 & 1 & 3 \\
\hline 18 & 6 & i & 3 \\
\hline 19 & 6 & & 3 \\
\hline 20 & 4 & & 3 \\
\hline 21 & 2 & & 3 \\
\hline 22 & 1 & & 3 \\
\hline 23 & I & & 3 \\
\hline 24 & 3 & 2 & \\
\hline 25 & 4 & & 2 \\
\hline 26 & 4 & 1 & \\
\hline 27 & 2 & 1 & \\
\hline 28 & 4 & & 1 \\
\hline 29 & 4 & & 1 \\
\hline 30 & 3 & & 1 \\
\hline 31 & 2 & & 1 \\
\hline 32 & 2 & & 1 \\
\hline 33 & 2 & & 1 \\
\hline
\end{tabular}


suppositories containing steroids. Bleeding continued throughout the rest of the day, and after an emergency telephone call he was brought by ambulance to the accident and emergency department. He was haemodynamically stable, and examination showed nothing remarkable apart from fresh blood leaking through the anal sphincter. Further examination and investigation showed no signs of haemorrhoids, but appearances on contrast enema were consistent with ischaemic colitis. This was managed conservatively, and over the next four days he passed smaller amounts of blood by the rectum associated with a fall in haemoglobin concentration of $15 \mathrm{~g} / \mathrm{l}$. He was reviewed six weeks later and had had no recurrence.

TABLE VI - Final diagnoses for patients who referred themselves to accident and emergency department and were admitted in order of length of stay in hospital

\begin{tabular}{|c|c|c|c|c|}
\hline $\begin{array}{l}\text { Case } \\
\text { No }\end{array}$ & $\begin{array}{c}\text { Age } \\
\text { (years) }\end{array}$ & Diagnosis & $\begin{array}{l}\text { Length of stay } \\
\text { (days) }\end{array}$ & Outcome \\
\hline 1 & 3 & Chest infection & $<1$ & Died $^{\star}$ \\
\hline 2 & 62 & Iridocyclitis & $<1$ & Followed up as outpatient \\
\hline 3 & 2 & Acute bronchitis & 1 & No follow up \\
\hline 4 & 11 & Viral infection & 1 & No follow up \\
\hline 5 & 3 Months & Upper respiratory tract infection & 1 & Followed up as outpatient \\
\hline 6 & 2 & Viral illness & 1 & No follow up \\
\hline 7 & 5 & Tonsillitis and otitis media & 1 & No follow up \\
\hline 8 & 1 Month & Colic & 1 & No follow up \\
\hline 9 & 24 & Eczema & 2 & Followed up as outpatient \\
\hline 10 & 23 & Rectal abscess & 2 & Followed up as outpatient \\
\hline 11 & 4 & Asthma & 2 & Followed up as outpatient \\
\hline 12 & 1 Month & Viral infection & 2 & Followed up as outpatient* \\
\hline 13 & 4 & Non-specific abdominal pain & 2 & No follow up \\
\hline 14 & 5 & Migraine & 2 & Followed up as outpatient \\
\hline 15 & 26 & Angioneurotic oedema & 2 & No follow up \\
\hline 16 & 1 & Bronchial asthma & 2 & Followed up as outpatient ${ }^{\star}$ \\
\hline 17 & 21 & Non-specific gastroenteritis & 3 & No follow up \\
\hline 18 & 25 & Hypertension and giycosuria (pregnant) & 3 & Followed up as outpatient \\
\hline 19 & 4 & Tonsillitis & 3 & No follow up \\
\hline 20 & 18 & Gluteal abscess & 3 & Followed up as outpatient \\
\hline \multirow[t]{2}{*}{21} & 2 & Upper respiratory tract infection and & & \\
\hline & & gastroenteritis & 3 & No follow up \\
\hline 22 & 2 & Abscess of right loin & 3 & Followed up as outpatient \\
\hline 23 & 4 Months & Upper respiratory tract infection & 3 & No follow up \\
\hline 24 & 9 Months & Viral upper respiratory tract infection & 3 & No follow up \\
\hline 25 & 5 & Tonsillitis & 3 & No follow up \\
\hline 26 & 4 & Meningitis & 3 & Died \\
\hline 27 & 9 Months & Upper respiratory tract infection & 5 & No follow up \\
\hline 28 & 1 & Measles & 5 & No follow up \\
\hline 29 & 36 & Cholesteatoma & 5 & Followed up as outpatient \\
\hline 30 & 63 & Diverticular disease & 6 & Followed up as outpatient \\
\hline 31 & 52 & Cellulitis of foot & 7 & Followed up as outpatient \\
\hline 32 & 6 Months & Gastroenteritis & 7 & No follow up \\
\hline 33 & 69 & Ischaemic colitis & 8 & Followed up as outpatient \\
\hline 34 & 1 & Asthma & 8 & Followed up as outpatient \\
\hline 35 & 57 & Asthma & 10 & No follow up \\
\hline 36 & 2 & Septicaemia & 12 & Followed up as outpatient ${ }^{\star}$ \\
\hline 37 & 27 & Asthma & 14 & No follow up \\
\hline 38 & 21 & Non-specific abdominal pain & 16 & Followed up as outpatient \\
\hline 39 & 86 & Cellulitis & 17 & No follow up \\
\hline 40 & 62 & Arterial ulcers & 18 & Followed up as outpatient \\
\hline 41 & 1 Month & Pyloric stenosis & 23 & Followed up as outpatient ${ }^{\star}$ \\
\hline 42 & 1 & Bronchopneumonia & 35 & Followed up as outpatient \\
\hline 43 & 44 & Depressive illness & 42 & Followed up as outpatient \\
\hline 44 & 6 Months & Bilateral fractured clavicles ${ }^{\star} \dagger$ & & \\
\hline 45 & 6 & Headaches $\dagger$ & & \\
\hline 46 & 10 & Tonsillitisf & & \\
\hline 47 & 1 & Diarrhoea $\uparrow$ & & \\
\hline
\end{tabular}

*Children aged $<5$ who attended from $9 \mathrm{pm}$ to $10 \mathrm{am}$

†Inpatient record could not be traced; diagnosis given is that reached in accident department.

Case 2-A 36 year old woman consulted her general practitioner with a week's history of left sided otalgia. She was given tablets and ear drops, but she then began to vomit and the pain got worse. Two days later her left ear began to discharge. She saw her doctor again and was given two sets of tablets, one of which was an analgesic. The pain, however, was not relieved. She had not slept for four nights. The next day she attended the accident and emergency department. On examination she was distressed and in pain. Her left external auditory meatus was full of pus, and she had tender left cervical lymphadenopathy. There was also a white discharge from her right ear. She was admitted to the ear, nose, and throat unit, where she underwent bilateral clearance by suction. A huge cholesteatoma was found on the left and a cholesteatoma with attic erosion on the right. She had long term follow up as an outpatient.

\section{Discussion}

The high rates of admission and referral to specialist clinics, as well as the two deaths of children, show that patients who refer themselves to the accident and emergency department for another opinion after consulting a general practitioner should not be ignored. The largest category of diagnosis was trauma. Understandably, patients turn to the accident and emergency department with traumatic conditions if they are not satisfied with their primary consultation. The fact that $72 \%(23 / 32)$ of patients were discharged with no follow up, however, does not suggest shortcomings in the primary management. The same was true for nontraumatic orthopaedic conditions. Gastrointestinal and respiratory problems formed a large proportion of the reasons for attendance, and the proportion of patients with these who were admitted was high.

If patients delay reconsulting a doctor until their symptoms have deteriorated and then attend the accident department because of a perceived sense of emergency most admissions might be expected to occur at least 24 hours after the first consultation (particularly as the first doctor presumably did not expect perceptible early deterioration). In fact the reverse was true, most admissions resulting from self referral within 24 hours after the primary consultation. Some patients may think that their doctor is not available late at night or be reluctant to disturb him or her. This did not, however, apply to the patients in this study because most attendances and admissions occurred before $9 \mathrm{pm}$. The picture emerges of admissions occurring after deliberate self referral for an opinion on a medical problem before $9 \mathrm{pm}$ without reference to the general practitioner, often in a child under 5 and within 24 hours after the first consultation.

A significantly greater proportion of children aged under 5 than of older patients were admitted. Their duration of stay was little different from the overall mean. The few admitted under the paediatric policy of admitting those attending at night after $9 \mathrm{pm}$ suggest that the policy is warranted as none were discharged home on the next day, some of the illness presented was serious, and the mean duration of stay ( 8.4 days) was longer than that of other patients (6.7 days).

The study has implications for both the accident and emergency department and general practice.

\section{ACCIDENT AND EMERGENCY}

All patients referring themselves to the accident and emergency department in this way should be seen by a doctor. Our results show that to prevent this would be unwise. Intervention should be offered only if the problem is a genuine emergency. If the criteria were less stringent the accident and emergency department might become an alternative source, if not first choice, of primary care for many patients. All of these attendances should be reported to the general practitioner. The low incidence of correspondence with general practitioners shown by this study is unacceptable. Unfortunately hospital letters are not always delivered by patients to their doctors. ${ }^{3}$

To implement these recommendations changes of policy would be required in many accident and emergency departments. These changes, though necessary to ensure improved care of patients, have their own implications. When it became known that it is departmental policy to see all patients who present in this way their numbers would inevitably increase. The system would also be open to abuse by patients, who might play off one doctor against another. Such abuse should be minimised by limiting intervention to genuine emergencies. In this way sick patients would have a better chance of receiving the treatment they require.

Not only would it be helpful for the general practi- 
tioner to be informed of these attendances, it would also be useful for the accident and emergency department to know more about the patients and perhaps even have details of previous consultations with their doctors. Communication between general practitioners and hospital accident units can be only in the best interests of patients. With advances in information technology there is good reason to believe that this will happen soon. ${ }^{+}$

\section{GENERAL PRACTICE}

We have identified failures in consultation in general practice and have shown that their distribution among general practitioners is not equal. We have also shown, within this group, an important amount of unreferred illness. Not every attendance or even admission necessarily reflected an error by the general practitioners (table VI), but if furnished with information about their patients' attendances to the department individual practitioners would be able to review their performances in consultations. In particular, they would be able $(a)$ to review the consultation to identify the cause of any breakdown in communication, $(b)$ to identify patients who might have unreasonable expectations, and $(c)$ if patients were admitted, particularly for some serious reason, to review their clinical decision and criteria for referral

Underreferral clearly exists and should be minimised in the best interests of patients. Information on underreferral, if supplied to general practitioners, could be a more useful indicator of failure to refer than is a low referral rate. The government's intention is to use referral rates as a means of identifying doctors who underrefer and overrefer ${ }^{6}$ (though referral rates are difficult to calculate and even more difficult to interpret). ${ }^{67}$ General practitioners with high referral rates will be asked to refer less and, presumably, those with low rates to refer more. We may, however, expect more emphasis on referring less for economic reasons. The problem with this approach is that there is an important distinction between underreferral and a low referral rate. Underreferral implies a possible error of management whereas there may be many good reasons for a low referral rate. A doctor with a low referral rate is not necessarily one who underrefers.

We suggest that it may be more useful for general practitioners to be informed of specific cases of possible underreferral than simply to be told that they have a low referral rate. At least in this way doctors with good reasons for having low referral rates will not be targeted unnecessarily by the authorities and those who may have average referral rates but whose patients are frequently admitted to hospital or referred on by the accident unit will be made aware of the fact and have some specific pointers from their own experience to help them prevent it. The data might be collected by computerised accident and emergency systems programmed to record this type of self referral. If this information was provided to general practitioners the number of referrals to consultants would probably increase.

This study has shown considerable unreferred illness. Any changes in practice arising from our recommendations would have economic and ethical repercussions, which would have to be resolved.

We thank Kathie Hornby, Janet Marshall, Agnes Hoban, and Barbara Glover for clerical help.

1 Davison AG, Hildrey ACC, Floyer MA. Use and misuse of an accident and emergency department in the east end of London. $\mathcal{F} R$ Soc Med 1983;76: $37-40$.

2 Yates DW. Nurse triage in the accident and emergency department. $f R$ Soc Health 1987;4:153-4.

3 Sherry $M$, Edmunds $S$, Touquet $R$. The reliability of patients in delivering their letter from the hospital accident and emergency department to their their letter from the hospital accident and emerge

4 Jones RVH. Aids to clinical management. In: Westcott R, Jones RVH, eds. Information handling in general practice. London: Croom Helm, 1988.

5 Department of Health and Social Security. Promoting better health: the government's programme for improving primary health care. London: HMSO, 1987. Cmnd 249.

6 Armstrong D, Britten N, Grace J. Measuring general practitioner referrals: patient, workload and list size effects. I R Coll Gen Pract 1988;38:494-7.

7 Roland M. General practitioner referral rates. Br Med f 1988;297:437-8.

8 Marinker M, Wilkin D, Metcalf DH. Referrals to hospital: can we do better? BrMed f 1988;297:461-4.

(Accepled 3 February 1989)

\title{
Chemical inactivation of HIV on surfaces
}

\author{
P J V Hanson, D Gor, D J Jeffries, J V Collins
}

Brompton and St Stephen's Hospitals, London

P J V Hanson, MRCP Medical Research Council research fellow

J V Collins, FRCP, consultant physician

Divison of Virology, St Mary's Hospital Medical School, London W2

D Gor, MSC, Medical Research Council research assistant

D J Jeffries, FRCPATH, consultant virologist

Correspunuince to: Dr P J V Hanson, Brompton

Hospital, London

SW3 6HP.

BrMed J 1989;298:862-4

\section{Abstract}

To assess whether alcohol and glutaraldehyde are effective disinfectants against dried HIV the virucidal effects of $70 \%$ alcohol (ethanol and industrial methylated spirit) and $1 \%$ and $2 \%$ alkaline glutaraldehyde were tested against cell associated and cell free HIV dried on to a surface. Virus stock $(100 \mu \mathrm{l})$ or 10000 cultured C8166 T lymphocytes infected with HIV were dried onto sterile coverslips and immersed in $2 \%$ and $1 \%$ alkaline glutaraldehyde and $70 \%$ ethanol for $\mathbf{3 0}$ seconds and one, two, four, and 10 minutes, there being an additional time point of $\mathbf{2 0}$ minutes for cell free virus disinfected with $70 \%$ industrial methylated spirit. In addition, virus stock in neat serum was tested with $1 \%$ and $2 \%$ alkaline glutaraldehyde to see whether the fixative properties of glutaraldehyde impair its virucidal properties. Virus activity after disinfection was tested by incubating the coverslips (cell associated virus) or the coverslips and sonicated cell free virus with C8166 T lymnincytes. The lymphocytes were examined for tr. urmation of syncytia and HIV antigens were assayed in the culture fluid. Both $2 \%$ and $1 \%$ alkaline glutaraldehyde inactivated cell free HIV within one minute; $2 \%$ alkaline glutaraldehyde also inactivated cell free virus in serum within two minutes, but a $1 \%$ solution was ineffective after 15 minutes' immersion. Cell associated HIV was inactivated by $2 \%$ alkaline glutaraldehyde within two minutes. Seventy per cent industrial methylated spirit failed to inactivate cell free and cell associated HIV within 20 and 15 minutes, respectively, and $70 \%$ ethanol did not inactivate cell free virus within 10 minutes.

Seventy per cent industrial methylated spirit and ethanol are not suitable for surface disinfection of HIV. Fresh $2 \%$ solutions of alkaline glutaraldehyde are effective, but care should be taken that they are not too dilute or have not become stale when used for disinfecting HIV associated with organic matter.

\section{Introduction}

Alcohols and 2\% alkaline glutaraldehyde are widely used for disinfection in laboratories, dental surgeries, and hospitals. Several investigators have reported successful inactivation of HIV in aqueous solutions by alcohols. In 1984 Spire et al, using a reverse transcriptase assay to detect surviving virus, found a $99 \%$ 